\title{
Functional and Molecular Characterization of Rat Intestinal Prolidase
}

\author{
MING HU, ZHENGQI CHENG, AND LIXING ZHENG \\ Department of Pharmaceutical Sciences, College of Pharmacy, Washington State University, Pullman, \\ Washington 99164-6510, U.S.A.
}

\begin{abstract}
Genetic deficiency of prolidase can lead to severe problems in child development, including mental retardation. However, the exact pathogenesis of the disease is unclear. To understand the enzyme's physiologic functions, we studied the regulation of rat intestinal prolidase. The results indicated that 1 ) the activities of intestinal prolidase and its kinetic parameters $\left(\mathrm{K}_{\mathrm{m}}\right.$ and $\left.V_{\max }\right)$ are site-dependent; 2) the jejunal prolidase activity was the most sensitive to the dietary restriction, and the duodenal and jejunal but not colonic kinetic parameters changed with dietary restriction; 3) the $\mathrm{pH}$ activity profile of jejunal prolidase at $24 \mathrm{~h}$ postfeeding was different from that at $48 \mathrm{~h}$ postfeeding, whereas the inhibition profiles of prolidase were qualitatively independent of dietary restriction; and 4) old-aged rats have lower prolidase activities in the small intestine. We also purified rat intestinal prolidase I to homogeneity. The characterization study indicated that the purified rat intestinal prolidase $\mathrm{I}$ is fairly similar to prolidase I from other species with a molecular weight of 116,000 , which consisted of two monomers, 58,000 D each. The
\end{abstract}

\section{ABSTRACT}

purified prolidase I has a $\mathrm{K}_{\mathrm{m}}$ value of $178 \mu \mathrm{M}$ and a $V_{\max }$ value of $601 \mu \mathrm{mol} \cdot \mathrm{min}^{-1} \cdot \mathrm{mg}$ protein ${ }^{-1}$. Screening of a rat intestinal cDNA library produced a $1.8-\mathrm{kb}$ fragment that encodes the rat intestinal prolidase. This enzyme has 494 deduced amino acid sequence, which is $96 \%$ or $86 \%$ identical to mouse or human erythrocyte prolidase I. This represents the first report of a successful attempt to purify and clone an intestinal prolidase and of investigation to study prolidase regulation by diet. (Pediatr Res 53: 905-914, 2003)

Abbreviations
HBSS, Hanks' balanced salt solution
Pro, proline
Gly-Pro, glycyl-proline
Phe-Pro, phenylalanyl-proline
SA, specific activities
SEC, size exclusion column

Prolidase is essential for the digestion and metabolism of protein, because it is the enzyme responsible for the metabolism of the most abundant protein digest glycyl-proline (GlyPro) and other imino-dipeptides (1). It is also important for endogenous protein metabolism and amino acid recycling, because it participates in collagen metabolism (2). It plays an important role in cellular growth because Chinese hamster cells that lack proline biosynthesis capability could grow normally as long as Gly-Pro and prolidase were present (1). Genetic deficiency of prolidase can lead to severe problems in child development, including abnormal joints, skin lesion (3), skin cancer (4), and mental retardation (5-7). In addition, abnormal prolidase activities were reported to be associated with certain side effects of drugs (8), liver cirrhosis (9), and hepatoma (10). Finally, prolidase has been targeted as a prodrug converting enzymes by various research groups, primarily for the purpose

Received January 20, 2003; accepted February 3, 2003.

Correspondence: Dr. Ming Hu, College of Pharmacy, Washington State University, Pullman, WA 99164-6510, U.S.A.; e-mail: minghu@wsu.edu

This work was supported by National Institutes of Health Grant HD33157.

DOI: 10.1203/01.PDR.0000064903.33501.FB of improving systemic or cellular bioavailability of poorly absorbed drugs $(11,12)$.

It is unclear how abnormal expression of prolidase contributes to the pathogenesis of various diseases associated with its deficiency. Previous studies have not generated a definitive cause for the pathogenesis of prolidase deficiency. For example, Dolenga and Hechtman (13) showed that fibroblasts obtained from symptomatic patients grew normally when medium was supplemented with proline. This result is inconsistent with clinical observation, where proline supplement therapy did not result in any significant improvement in skin lesions (6). In another study, high concentrations of X-Pro were shown to be nontoxic to Chinese hamster cells lacking proline biosynthesis capability (1), but clinical symptoms were associated with a higher level of circulatory Gly-Pro (6).

The above analysis suggests that in vivo models may be better suited for determining the physiologic functions of prolidase, which was the main reason that we chose the rat model. Because prolidase located in the intestinal epithelium will hydrolyze dietary dipeptides X-Pro as soon as they are absorbed into the cells, its characterization will help us to 
understand how it participates in the absorption and recycling of dietary as well as endogenous amino acids and how its functional expression is regulated in the intestine. In the present study, we systematically determined the prolidase activity along the intestinal tract, purified intestinal prolidase I to homogeneity, and then determined the kinetic properties of purified intestinal prolidase I. We further cloned intestinal prolidase I from a rat intestinal cDNA library and compared it with reported amino acid sequence from mouse and human erythrocyte prolidase I.

\section{METHODS}

\section{Materials}

Phenylalanyl-proline (Phe-Pro), Gly-Pro, Phe, $\mathrm{MgCl}_{2}$, $\mathrm{MnCl}_{2}$, mercaptoethanol, DTT, and Hanks' balanced salt solution (HBSS; powder form) were purchased from Sigma Chemical Co. (St. Louis, MO, U.S.A.). Resource-S and Resource-Q columns were purchased from Pharmacia (Uppsala, Sweden).

\section{Preparation of Intestinal Segments}

The animal experiment procedures were approved by the Washington State University Institutional Animal Use and Care Committee. Sprague Dawley rats were fasted for 24 or $48 \mathrm{~h}$ with free access to water. Rats that weighed between 250 and $350 \mathrm{~g}$ were killed, and the whole intestine was then removed, washed with ice-cold saline, and kept in an ice-cold HBSS buffer. The rat small intestine was segmented, $10 \mathrm{~cm}$ each, from duodenum to ileum. A 10-cm segment of colon immediately adjacent to the ileocolonic junction was also removed for enzyme preparation (note: The rat colon was approximately $14 \mathrm{~cm}$ in length). These segments were stored in an ice-cold HBSS buffer until use.

\section{Crude Enzyme Fractions}

The mucosal cells were removed by scraping with a spatula, and diluted to a solution that contains approximately $100 \mathrm{mg}$ wet cells per milliliter of $\mathrm{pH}$ 7.4 HBSS supplemented with 1 $\mathrm{mM}$ of $\mathrm{Mg}^{++}$and $\mathrm{Mn}^{++}$. The cells were then homogenized using an Omni Mixer (Sorvall, Norwalk, CT, U.S.A.) at approximately $8000 \mathrm{rpm}$ for $3 \mathrm{~min}$ in a $4^{\circ} \mathrm{C}$ water bath. The homogenate was then centrifuged at $35,000 \times g$ for $20 \mathrm{~min}$ at $4^{\circ} \mathrm{C}$, and the supernatant was filtered with a $0.22-\mathrm{mm}$ filter. The "filtered homogenate preparation" or "crude prolidase" was kept at $4^{\circ} \mathrm{C}$ until preparations from different segments were used for subsequent studies.

\section{Enzyme Purification Procedures}

Step 1. The filtered homogenate preparations from various segments were pooled and lyophilized overnight. The dried powder was then dissolved in HPLC water and dialyzed against a $\mathrm{pH} 8.0$ Tris-HCl buffer $(50 \mathrm{mM})$ overnight.

Step 2. The dialyzed sample was allowed to pass through a strong cation exchange Resource-S column using pH $4.52-(\mathrm{N}-$ morpholino)ethanesulfonic acid buffer $(50 \mathrm{mM})$ with increas- ing concentration of $\mathrm{NaCl}$ via a Varian 5000 gradient liquid chromatography system (Palo Alto, CA, U.S.A.). Fractions that contained prolidase were then pooled again and lyophilized overnight.

Step 3. The dried powder was then dissolved in $\mathrm{pH} 8.0$ Tris- $\mathrm{HCl}$ buffer and dialyzed overnight against a $\mathrm{pH} 8.0$ Tris$\mathrm{HCl}$ buffer that contained $1 \mathrm{mM}$ each of DTT and $\mathrm{Mn}^{++}$.

Step 4. The dialyzed sample was then passed through a strong anion exchange Resource-Q column. Prolidase was eluted using $\mathrm{pH} 8.0$ Tris- $\mathrm{HCl}$ buffer with an increasing concentration of $\mathrm{NaCl}$ via the Varian 5000 gradient liquid chromatography system.

Step 5. Fractions that contain the highest prolidase activity were then loaded into a Centricon $10(\mathrm{MW}$ cutoff $=10,000)$ concentrator, and the samples were concentrated and washed with HPLC water that contained $1 \mathrm{mM}$ each of DTT and $\mathrm{Mn}^{++}$.

Step 6. The concentrated samples were injected into a size exclusion column (SEC-400S, BioRad) and eluted with $\mathrm{pH} 7.4$ Tris- $\mathrm{HCl}$ buffer $(50 \mathrm{mM})$ containing $150 \mathrm{mM} \mathrm{NaCl}$ and $0.5 \%$ ( vol/vol) mercaptoethanol.

\section{Kinetic Assay of Enzyme Activities}

Enzyme stock. For crude prolidase preparations from the small intestine, the fraction was first diluted 1:40 to obtain a stock solution for enzyme assay. For crude prolidase fraction from the large intestine, the fraction was diluted 1:2 to obtain a stock solution for enzyme assay. For purified enzyme preparations that did not contain appropriate amounts of $\mathrm{Mn}^{++}$, the enzyme stock solution (with mercaptoethanol) was incubated with $1 \mathrm{mM} \mathrm{Mn}^{++}$for $10 \mathrm{~min}$ before the experiments to display maximum activity. The activity assay proceeded using an enzyme concentration that can hydrolyze approximately $20 \%$ of $50 \mu \mathrm{M}$ Phe-Pro solution in 10-15 min. This condition was used to allow optimal determination of initial rates of hydrolysis (or enzyme activity) with relatively good throughput and low relative variability in the sampling time.

Activity assay. A standard assay was performed by thoroughly mixing $50 \mu \mathrm{L}$ of $1 \mathrm{mM}$ Phe-Pro, $50 \mu \mathrm{L}$ of enzyme assay stock solution, and $900 \mu \mathrm{L}$ HBSS buffer and letting the reaction proceed for $10 \mathrm{~min}$ at $37^{\circ} \mathrm{C}$. At the end of the reaction time, $20 \mu \mathrm{L}$ of phosphoric acid $(0.9 \mathrm{~N})$ was added to quench the reaction to $\mathrm{pH} 2$. The sample was then frozen at $-20^{\circ} \mathrm{C}$ until assay.

Determination of factors affecting prolidase activity. Determination of saturability of an enzyme-catalyzed reaction is a necessary component of functional characterization. For measuring activities at different concentrations, the portion of enzyme stock solution was kept constant, whereas the portion of substrate buffer and/or HBSS buffer was changed so that the final condition was obtained as required.

\section{HPLC Assay of Phe}

The HPLC conditions for the assay of Phe, a product of Phe-Pro hydrolysis by prolidase, were as follows: column, Beckman Ultrasphere C-18, $5 \mathrm{~mm}, 0.4 \times 25 \mathrm{~cm}$; detector wavelength, $210 \mathrm{~nm}$; mobile phase, $80 \% 50 \mathrm{mM} \mathrm{NaH}_{2} \mathrm{PO}_{4}(\mathrm{pH}$ 
5) plus $20 \% \mathrm{CH}_{3} \mathrm{OH}$; flow rate, $0.8 \mathrm{~mL} / \mathrm{min}$; retention time, 6 min; sensitivity, 100 pmol.

\section{Statistical Analysis}

ANOVA or Student $t$ test was used throughout the study to compare the difference between results of the controlled experiments and that of the test experiments (e.g. different $\mathrm{pHs}$ ). A significance level of 5\% $(p=0.05)$ was used as the criterion to determine whether the difference was statistically significant.

\section{Protein assay}

Bradford's method was used with BSA as standard (14). The reagent was purchased from BioRad, and protein was quantified per the manufacturer's suggestion.

\section{Electrophoresis of Protein}

Electrophoresis of prolidase was performed according to standard procedures (15-18). Separated proteins were stained with Coomassie brilliant blue R-250 in appropriate acidic buffer $(16,18)$.

\section{Screening for Positive cDNA From Rat Intestinal cDNA Library}

The rat intestinal cDNA library, lambda ZAP vector, was provided by Prof. Kazuhiro Okada (Department of Cell Biology, Baylor College of Medicine, Houston, TX, U.S.A.). Recombinant plaques $(200,000)$ were screened with a human prolidase cDNA probe that was a gift from Prof. Fumi Endo (National Children's Medical Research Center, Tokyo, Japan). The cDNA probe was randomly primed with the ${ }^{32} \mathrm{P}$ label. Nitrocellulose filters were prehybridized at $42^{\circ} \mathrm{C}$ in a hybridization solution from GIBCO BRL (Grand Island, NY, U.S.A.). Hybridization was carried out in the same solution containing ${ }^{32} \mathrm{P}$-labeled cDNA probe at $42{ }^{\circ} \mathrm{C}$. The filters were washed at $42^{\circ} \mathrm{C}$ four times with $50 \%$ formamide and five times with $0.1 \%$ SDS in saline sodium citrate buffer and were exposed overnight at $-70^{\circ} \mathrm{C}$ to Kodak X-Omat AR film (New Haven, CT, U.S.A.).

\section{Sequence Analysis of Rat Intestinal Prolidase in puc19 Vector}

The inserts released from the phage DNA of the lambda ZAP library were relegated into puc19 vector at the E.coR1$K p n I$ site. Sequencing of the insert cDNA was carried out by dideoxy chain termination technique. Both strands of the cDNA were manually sequenced by using synthetic primers, derived from the human prolidase cDNA sequence. Only three of 20 primers synthesized according to human prolidase cDNA sequence were not suitable for priming.

\section{Northern Blot Analyses}

Two rats were fasted (i.e. no food except water) for 24 and $48 \mathrm{~h}$, respectively. Total RNAs were prepared from rat intestines, respectively, by TriZol reagent following the manufac- turer's instruction (GIBCO BRL), separated on 1\% agarose gel containing $2.2 \mathrm{M}$ formaldehyde, and transferred to nitrocellulose membrane. The probe for rat intestinal prolidase mRNA was the rat intestinal prolidase cDNA made from rat intestinal cDNA library in our laboratory and labeled using randomly primed DNA labeling kit and ${ }^{32} \mathrm{PdCTP}$; specific activity was approximately $10^{8} \mathrm{cpm} / \mu \mathrm{g}$ of DNA. Hybridization was performed at $42^{\circ} \mathrm{C}$ for $18 \mathrm{~h}$ with the ${ }^{32} \mathrm{P}-\mathrm{cDNA}$ probe and $2 \times$ prehybridization/hybridization solution following a procedure recommended by the manufacturer (GIBCO BRL). After the blot was exposed to an $\mathrm{x}$-ray film overnight, densities of the dark bands were determined by cutting the area of the blot corresponding to the dark bands of the film and counting the radioactivity.

\section{RESULTS}

\section{Time Course of Hydrolysis}

The hydrolysis of Phe-Pro by the jejunal prolidase as measured by the appearance of Phe in the reaction media followed a linear relationship with time (up to $45 \mathrm{~min}$, or approximately $35 \%$ hydrolyzed) under this condition (Fig. 1) using crude prolidase prepared from rats fasted for 24 and $48 \mathrm{~h}$, respectively. This relationship was also observed in other intestinal segments tested. Therefore, later studies using homogenate all were performed for 10-15 min, resulting in approximately $10-15 \%$ hydrolysis.

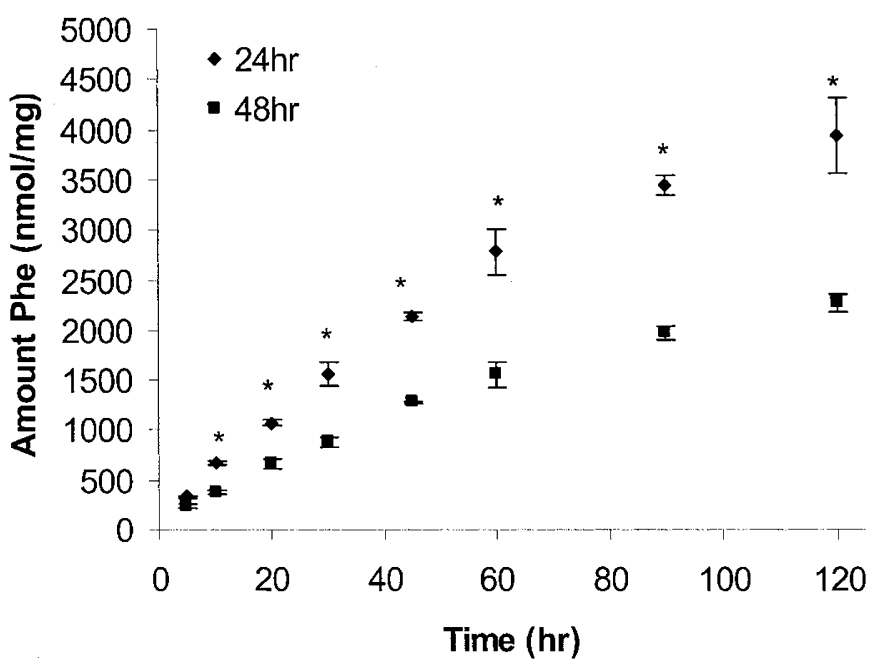

Figure 1. Time course of hydrolysis of $50 \mu \mathrm{M}$ Phe-Pro by jejunal prolidase prepared from rats fasted for $24 \mathrm{~h}(\bullet)$ and $48 \mathrm{~h}(\boldsymbol{\square})$. The experiments were performed at $37^{\circ} \mathrm{C}$ after samples containing the substrate and enzyme were thoroughly but not rigorously mixed. The prolidase activity was abolished at the end of experimental period using $0.9 \mathrm{~N} \mathrm{H}_{3} \mathrm{PO}_{4}$ to acidify the samples to $\mathrm{pH}$ 2, and the amount of product Phe was analyzed using HPLC. Each data point was the average of three determinations, and the error bar was the SD of the mean. The prolidase preparations were pooled from three rats. Effect of fasting time was compared at each data point. *Difference between the amounts of metabolite (Phe) formed using crude intestinal prolidase prepared from rats fasted for a different period of time was statistically significant according to an unpaired $t$ test. 


\section{Prolidase Distribution}

Prolidase activities in this and subsequent studies were normally expressed as specific activities (SA). When we determined SA of prolidase in different regions (or sites) of the intestine, the results indicated that the prolidase was predominantly presented in the small intestine, where its SA was 4- to 5 -fold higher $(p<0.05)$ than colon (Fig. $2 A)$. By taking total enterocyte protein into consideration, the total activities of enterocyte prolidase per centimeter of the small intestine are
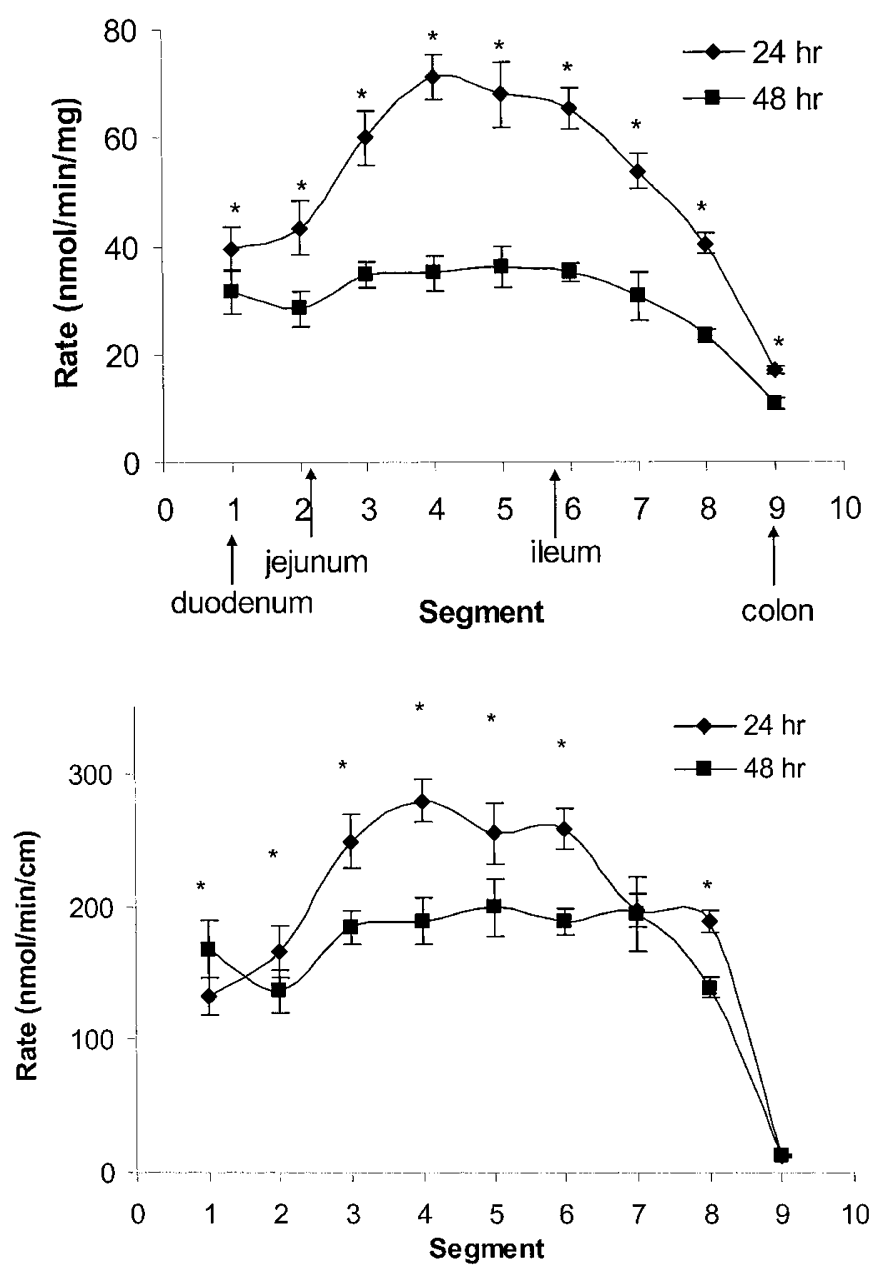

Figure 2. Distribution patterns of prolidase along the intestine. Each segment represents approximately $10 \mathrm{~cm}$ of intestine. 1, duodenum; 2, duodenum+jejunum; 3-5, jejunum; 6 , jejunum+ileum; 7 and 8 , ileum; 9 colon immediately adjacent to the ileocolonic junction. This designation is based on the fact that you can localize duodenum knowing that it is $10-15 \mathrm{~cm}$ long and ends at the ligament of Treitz. The rest of the small intestine is approximately $60 \%$ jejunum and $40 \%$ ileum, although there is not a clear anatomical marking between the jejunum and the ileum. The enzyme was prepared according to methods described in "Methods." Prolidase activity was determined at $37^{\circ} \mathrm{C}$ using $50 \mu \mathrm{M}$ Phe-Pro as the substrate. The results were then either normalized against protein content (per milligram; top) or the intestinal length (per centimeter; bottom). Each data point was the average of three determinations, and the error bar was the SD of the mean. The prolidase preparations were pooled from three rats. According to one-way analysis of the data, the differences in prolidase activities were significant between segments regardless of whether the rats were fasted for $24 \mathrm{~h}(\bullet)$ or $48 \mathrm{~h}(\boldsymbol{\square})$ or whether SA or total activities per centimeter were used. We also analyzed the effect of fasting time at each segment. *Significant differences in prolidase activities because of fasting.
10- to 20 -fold $(p<0.05)$ higher than colon (Fig. $2 B)$, because amounts of protein contained in the mucosal enterocyte homogenate from the small intestine are usually much higher than colonic enterocyte homogenate. As a reference point, the crude prolidase activity in the rat colon homogenate $(15-30 \mathrm{nmol}$. $\min ^{-1} \cdot \mathrm{mg}$ protein $\left.{ }^{-1}\right)$ was close to that in the Caco-2 cell lysate $\left(30-50 \mathrm{nmol} \cdot \mathrm{min}^{-1} \cdot \mathrm{mg}\right.$ protein $\left.{ }^{-1}\right)$, a human intestinal cell line of colon adenocarcinoma (19).

\section{Effect of Fasting}

Animals that were fasted for $48 \mathrm{~h}$ had a significantly decreased SA in all segments of the intestine except duodenum. The effect was more pronounced in the middle part of the small intestine than in the colon (Fig. 2A). Interestingly, the total prolidase activities per centimeter, which are derived by multiplying the amount of protein present in each segment and dividing by $10 \mathrm{~cm}$, showed differences mostly in the middle one half of the small intestine (Fig. 2B).

\section{Kinetic Characterization of SA of Homogenates}

Kinetic analysis of rate versus concentration curves (Fig. 3) yielded the apparent values of $\mathrm{K}_{\mathrm{m}}$ and $V_{\max }$ for prolidasecatalyzed hydrolysis of Phe-Pro in duodenum (segment 1), jejunum (segment 4), and colon (segment 9; Table 1). These results indicated that both the $V_{\max }$ and $\mathrm{K}_{\mathrm{m}}$ values were changed depending on the site and time postfeeding. However, the amount of total protein in each preparation did not change significantly with fasting (not shown).

\section{pH Effect}

Different optimal maximum $\mathrm{pH}$ has been reported for partially purified prolidase I and prolidase II, derived from leukocytes (20). The optimal $\mathrm{pH}$ for prolidase I was approximately 7.2 and for prolidase II was approximately 8.0 (20).

The $\mathrm{pH}$ activity profiles of rat intestinal prolidase after the rats were fasted for 24 and $48 \mathrm{~h}$ are shown in Figure 4. $\mathrm{pH}$ had a significant $(p<0.05)$ effect on the prolidase activities using homogenates prepared from all three regions of the rat intestine. The results indicated that optimal activity of prolidase is always at approximately $\mathrm{pH} 6$, which did not change significantly with time postfeeding. However, the jejunal and clonal prolidase activities at $\mathrm{pH} 7 \mathrm{did}$ change significantly $(p<0.05)$ with dietary restriction, whereas the duodenal prolidase did not. At all the $\mathrm{pH}$ tested, SA of jejunal prolidase was significantly higher $(p<0.05)$ than SA of duodenum and colon, except at $\mathrm{pH} 9$, where duodenal SA was similar to jejunal SA in the 48-h postfeeding sample.

\section{Effect of Inhibitors}

Various potential inhibitors of prolidase were tested to determine their effects on enzyme-catalyzed Phe-Pro hydrolysis via crude prolidase (Fig. 5). The results indicated that captopril, $\mathrm{ZnCl}$, and proline but not L-leucine significantly $(p<$ 0.05 ) inhibited the hydrolysis of Phe-Pro using homogenates from duodenum, jejunum, and colon. In addition, the inhibition patterns by this set of inhibitors were qualitatively similar, but 

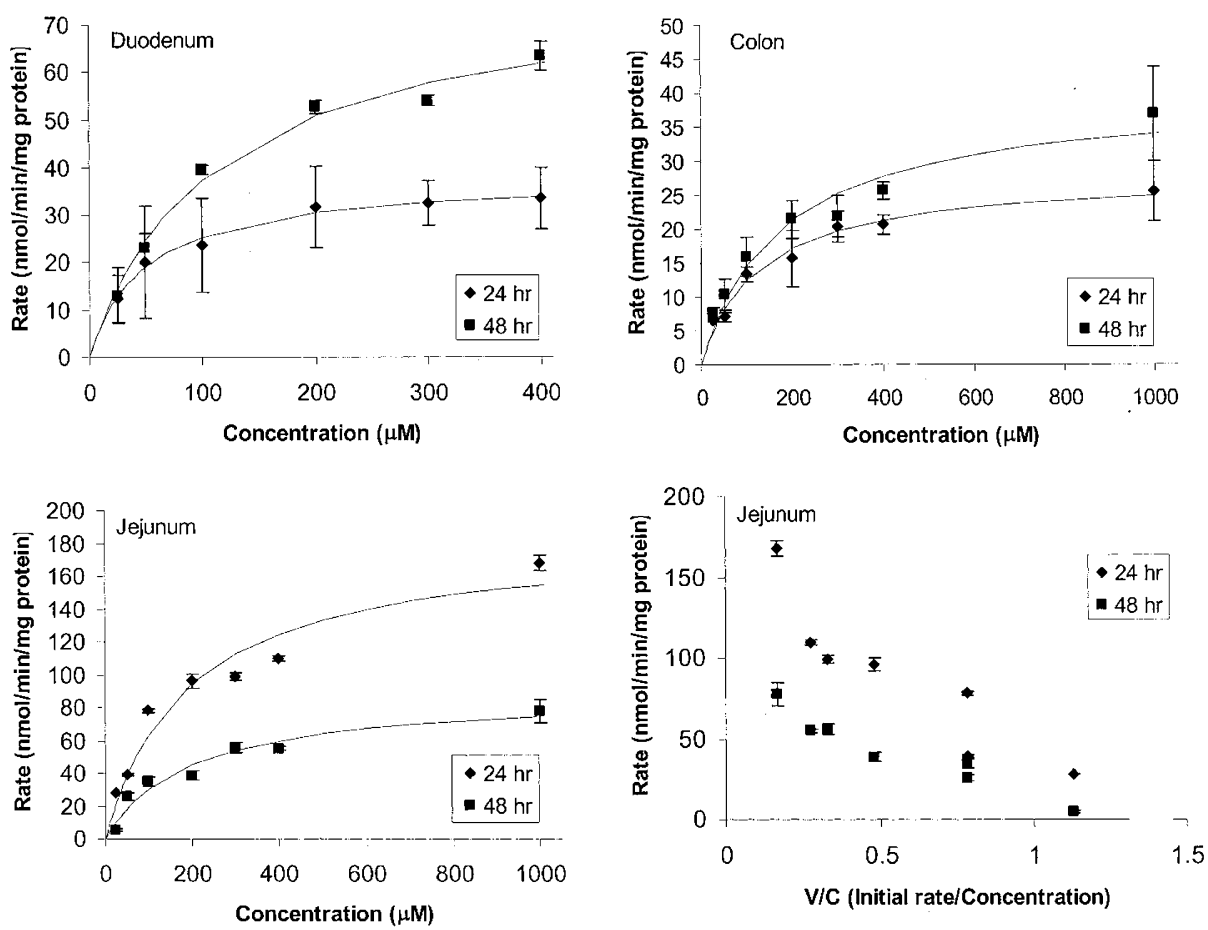

Figure 3. Concentration-dependent hydrolysis of Phe-Pro by filtered homogenate preparations from duodenum or segment 1 (top left, labeled as duodenum), jejunum or segment 4 (bottom left), and colon or segment 9 (top right), using rats fasted for $24 \mathrm{~h}(\diamond)$ and $48 \mathrm{~h}(\square)$. Experiments were performed and activities were measured following procedures described in "Methods." The concentrations used were between 25 and $1000 \mu \mathrm{M}$. Each data point was the average of three determinations, and the error bar was the SD of the mean. The prolidase preparations were pooled from three rats. Also shown were representative Eadie-Hofstee plots using jejunum (segment 4; bottom right) at $24 \mathrm{~h}(\bullet)$ and $48 \mathrm{~h}(\boldsymbol{\square})$ postfeeding time, respectively. A linear regression analysis of the data (line not shown) generated an $\mathrm{R}^{2}$ of 0.82 for the 24 -h curve and 0.73 for the 48 -h curve.

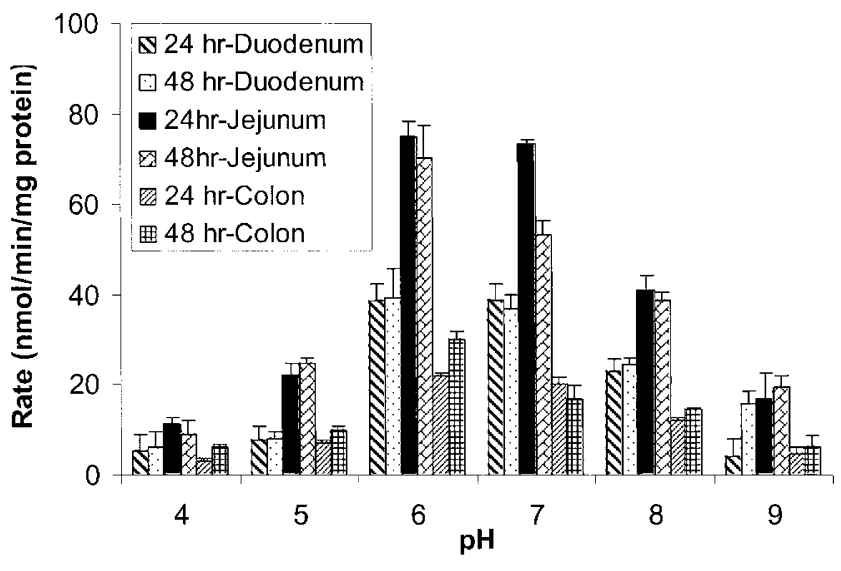

Figure 4. The $\mathrm{pH}$ activity profiles of jejunal prolidase obtained from rats fasted for 24 and $48 \mathrm{~h}$. The experiments were performed at $37^{\circ} \mathrm{C}$ for $10 \mathrm{~min}$ in HBSS buffers at different pHs. Each data point is the average of three determinations, and the error bar is the SD of the mean. The prolidase preparations were pooled from two rats. Duodenal (segment 1) prolidase after 24-h dietary restriction is designated as $24 \mathrm{~h}$-duodenum (first slashed bars in each group), after $48 \mathrm{~h}$ dietary restriction is designated as $48 \mathrm{~h}$-duodenum (dotted bars). Similarly, jejunal prolidase (segment 4) was designated as 24 h-jejunum (solid bars) and $48 \mathrm{~h}$-jejunum (slashed brick bars), whereas colonic (segment 9) prolidase as $24 \mathrm{~h}$-colon (fifth slashed bars) and $48 \mathrm{~h}$-colon (stacked squares), respectively. According to a one-way ANOVA, the effects of $\mathrm{pH}$ were statistically significant.

they also had some quantitative differences. For example, after 24-h dietary restriction, duodenal and colonic prolidase was inhibited more by captopril $(100 \%$ and $94 \% ; p<0.05)$ than by
$\mathrm{ZnCl}_{2}(65 \%$ and $81 \% ; p<0.05)$, whereas jejunal prolidase was similarly inhibited by both ( $84 \%$ versus $89 \%)$.

\section{Effect of Aging}

Some elderly rats have poor nutrition and can lose weight. In the small intestine, aged rats ( $487 \mathrm{~d}$ old) had generally less prolidase activity $(p<0.05)$ than younger rats $(64 \mathrm{~d}$ old $)$. The difference in SA approached 1-fold at the upper intestine (Fig. 6) but was less in the colon (Fig. 6).

\section{Rat Intestinal Prolidase I Purifications}

This is a multistep procedure that produces the highest reported purity of the intestinal prolidase I. The purification efficiency and yield are presented in Table 2. The following are the results of individual elution step and their representative elution profiles.

Ion exchange columns. The results (Table 2) indicated that purification through Resource-S column increased the SA by 29 times when pooled fractions 3-5 were used (Fig. 7). This SA decreased when fraction 1 was also used. After the eluent portions containing the prolidase activities were pooled and processed as described, they were loaded onto a Resource-Q column. The results indicated that the Resource-Q column is by far the best for the purification of this enzyme (42 times; Fig. 8), as demonstrated by other investigators $(16,21)$.

Size exclusion column (SEC-400S). This step yielded an enzyme with a specific activity (510 U; Fig. 9). Using molec- 
Table 1. Kinetic parameters describing the hydrolysis of Phe-Pro by crude prolidase in different segments of the intestine following different postfeeding time

\begin{tabular}{|c|c|c|c|c|c|c|}
\hline \multirow{2}{*}{$\begin{array}{c}\text { Postfeeding } \\
\text { time }(\mathrm{h})\end{array}$} & \multicolumn{3}{|c|}{$\mathrm{K}_{\mathrm{m}}(\mathrm{mM})$} & \multicolumn{3}{|c|}{$\mathrm{V}_{\max }(\mathrm{nmol} / \mathrm{min} / \mathrm{mg}$ protein $)$} \\
\hline & Duodenum & Jejunum & Colon & Duodenum & Jejunum & Colon \\
\hline 24 & 50 & 190 & 126 & 38.1 & 183.9 & 28.1 \\
\hline
\end{tabular}

The experiments were performed with $25-1,000 \mu \mathrm{M}$ Phe-Pro in $\mathrm{pH} 7.4$ HBSS buffer for $10 \mathrm{~min}$ at $37^{\circ} \mathrm{C}$. The kinetic parameters were determined using nonlinear regression analysis of the data such as those presented in Figure 3.

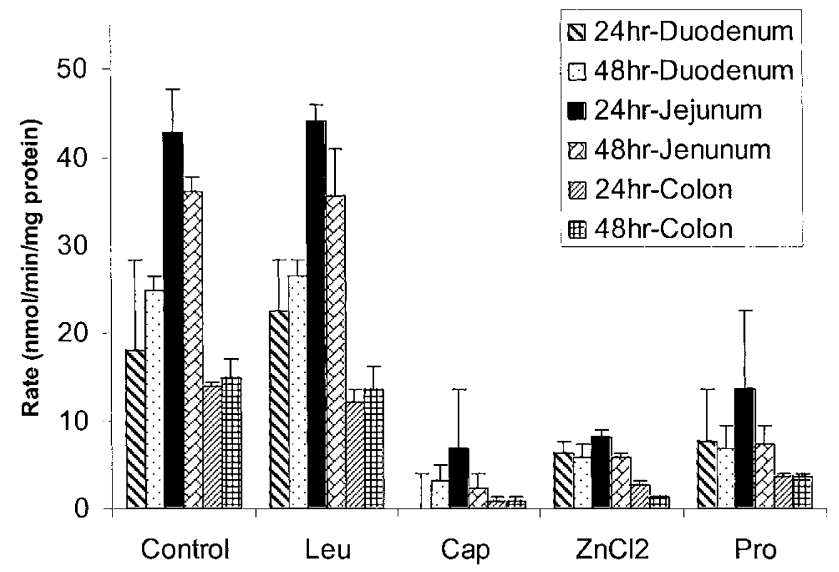

Figure 5. Effects of L-leucine (Leu; $2 \mathrm{mM}$ ), L-proline (Pro; $2 \mathrm{mM})$, captopril (Cap; $0.1 \mathrm{mM})$, and $\mathrm{ZnCl}_{2}(2 \mathrm{mM})$ on the hydrolysis of Phe-Pro by jejunal prolidase obtained from rats that were fasted for 24 and $48 \mathrm{~h}$. The experiments were performed at $37^{\circ} \mathrm{C}$ for $10 \mathrm{~min}$ in $\mathrm{pH} 7.4 \mathrm{HBSS}$ buffers containing different inhibitors. According to a one-way ANOVA, the effects of inhibitors with exception of L-leucine were statistically significant. Each bar is the average of three determinations, and the error bar is the SD of the mean. The legend designation in this figure is the same as those presented in Figure 4.

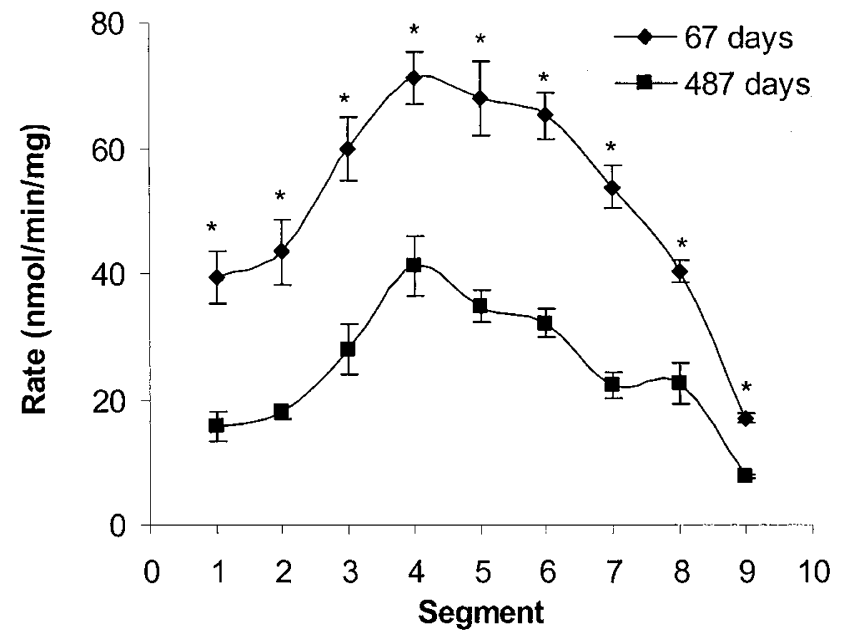

Figure 6. Distribution of prolidase activities along the intestinal tract in young adult rats and aged rats after $24-\mathrm{h}$ fasting. The method for generating the SA and activities per centimeter of intestine was the same as in Figure 2. The anatomical regions of the rat intestine were the same as those shown in Figure 2. According to one-way analysis of the data, the differences in prolidase activities were significant between segments regardless of whether the rats were young or old. We also analyzed the effect of age at each segment. *Significant difference because of age.

ular weight standard supplied by Bio-Rad and activity assay, the molecular weight of our enzyme was determined to be $116,000 \mathrm{D}$ (using the peak activity time as the peak elution
Table 2. Enrichment and yield of the prolidase purification procedure

\begin{tabular}{lccc}
\hline \multicolumn{1}{c}{ Preparations } & \multicolumn{1}{c}{$\mathrm{SA}^{*}$} & $\begin{array}{c}\text { Purification } \\
\text { times }\end{array}$ & \% Yield $\dagger$ \\
\hline Filtered homogenate $\$$ & 0.05 & 1 & - \\
Resource-S & 1.44 & 28.8 & $50 \%$ \\
Resource-Q & 59.8 & 1196 & $15 \%$ \\
SEC-400S & 134 & 2680 & $6 \%$ \\
& 510 (calculated $\|)$ & & \\
Commercial§ & 33.4 & & \\
& 127 (calculated $\|)$ & & \\
\hline
\end{tabular}

* SA were expressed as $\mathrm{U}$ or $\mu \mathrm{mol} \cdot \min ^{-1} \cdot \mathrm{mg}$ protein $^{-1}$, which was equivalent to $1 \mu \mathrm{mol}$ Phe formed $\cdot \min ^{-1} \cdot \mathrm{mg}_{\text {protein }}{ }^{-1}$ using $50 \mu \mathrm{M}$ Phe-Pro as substrate at $37^{\circ} \mathrm{C}$ in $\mathrm{pH} 7.4 \mathrm{HBSS}$ solution. Activity measured using $1 \mathrm{mM}$ Phe-Pro will be significantly higher (see calculated activities).

$\uparrow$ The $\%$ yield represents the total accumulative yield of the procedure up to a specific step.

$\$$ Filtered homogenate were pooled from segments $1-8$ (from duodenum to jejunum).

$\S$ For purified prolidase I, the calculated value was based on a concentration of $1,000 \mu \mathrm{M}, \mathrm{K}_{\mathrm{m}}$ of $178 \mu \mathrm{M}$, and $\mathrm{V}_{\max }$ of $601 \mathrm{U}$ (Fig. 9). The reason for using this calculated SA is that the SA reported by other investigators was obtained using 1,000 $\mu \mathrm{M}$ Phe-Pro or Gly-Pro 15, 18, 22. For commercial prolidase, the calculated activities were obtained using the ratio between SA at $50 \mu \mathrm{M}$ and at $1,000 \mu \mathrm{M}$ calculated using purified rat prolidase I.

|| Purchased from Sigma (catalog\# P6675), labeled as having a maximum activity of $100-200 \mathrm{U}$ at $37^{\circ} \mathrm{C}$ in $\mathrm{pH} 8.0$ buffer.

time), similar to prolidase I reported in humans $(16,22)$. This molecular weight is achievable only when DTT is added to protect prolidase before the SEC purification step. In the absence of DTT, the enzymes break into two monomers (molecular weight $=58,000$ determined by SEC). This latter molecular weight is consistent with a molecular weight of approximately 59,000 obtained from SDS-PAGE gel (not shown).

\section{Kinetic Characterization of Purified Rat Prolidase I}

The $\mathrm{K}_{\mathrm{m}}$ and $V_{\max }$ values were determined using purified prolidase and found to be $178 \mu \mathrm{M}$ and $601 \mathrm{U}$ or $601 \mu \mathrm{mol}$. $\min ^{-1} \cdot$ mg protein $^{-1}$ (Fig. 10). The Eddie-Hofstee plot of the data generated a straight line $\left(\mathrm{R}^{2}=0.979\right)$, suggesting that the enzyme preparation has one $\mathrm{K}_{\mathrm{m}}$ value. The calculated rate of hydrolysis at $1 \mathrm{mM}$ Phe-Pro concentration is $501 \mu \mathrm{mol} \cdot \mathrm{min}^{-1}$ - $\mathrm{mg}$ protein $^{-1}$, which is the value reported in Table 2.

\section{Cloning of Rat Intestinal Prolidase}

Screening of rat intestinal cDNA library created 40 positive clones, of which 10 were purified. The inserts were released by E.coR1 and KpnI digestion and separated on 1\% agarose gel. The inserts have sizes of approximately $1.4,1.6$, and $1.8 \mathrm{~kb}$, 


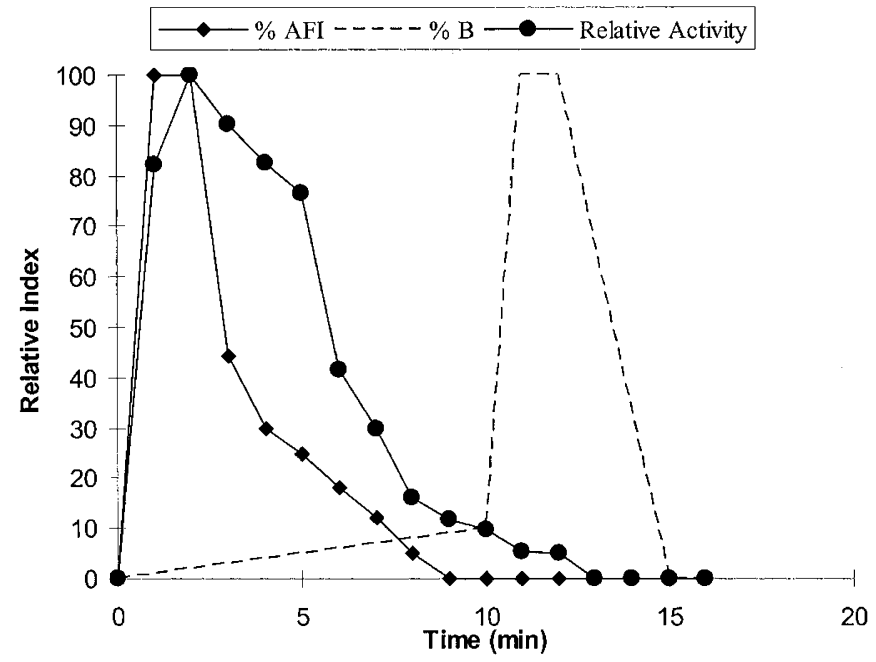

Figure 7. A representative elution profile of prolidase preparation through the Resource-S column $(1 \mathrm{~mL})$. Mobile phase A was 2-(N-morpholino)ethanesulfonic acid-HCl buffer (50 mM, pH 4.5), and mobile phase B was mobile phase A plus $1 \mathrm{M} \mathrm{NaCl}$. The dotted line represents percentage mobile phase $\mathrm{B}$ when running a gradient HPLC method. The absorbance profile $(100 \%=0.05$ absorbance unit; \&OV0049;) was generated using a wavelength of $280 \mathrm{~nm}$ and normalized as percentage of the maximal value in the run or \%AFI, which is a measure of the relative absorbance value. The enzyme activity assay was performed at $37^{\circ} \mathrm{C}$ after a $50-\mu \mathrm{L}$ portion of the effluent fraction (upon appropriate dilution) was allowed to react with $50 \mu \mathrm{M}$ Phe-Pro for $10 \mathrm{~min}$. Activities were again normalized against the highest activities (set at 100\%) and plotted against fractions collected (-). Each fraction is a 1-mL sample collected over $1 \mathrm{~min}$.

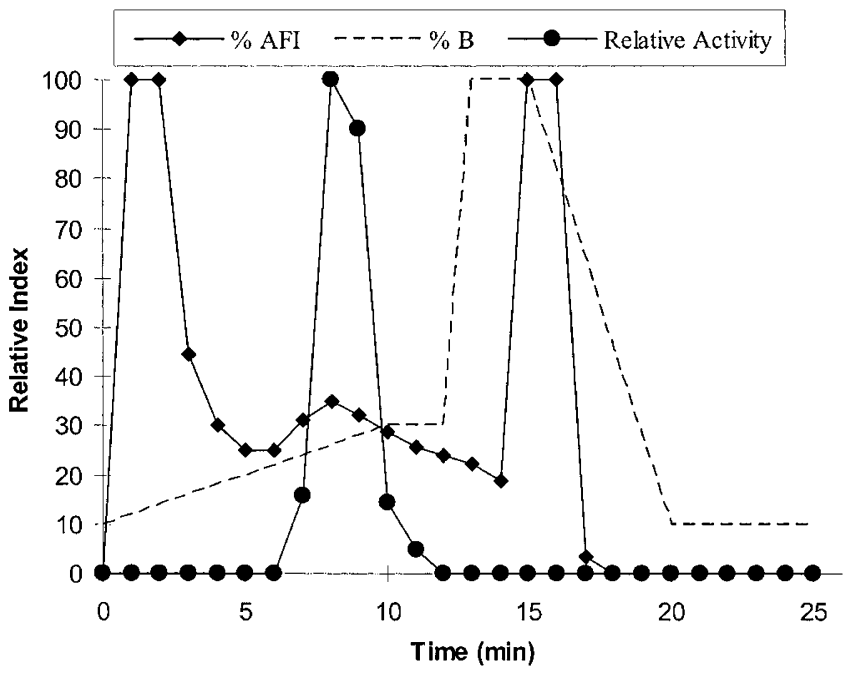

Figure 8. Elution profile of prolidase preparation through the Resource-Q column $(1 \mathrm{~mL})$. Mobile phase A was Tris- $\mathrm{HCl}$ buffer $(50 \mathrm{mM}, \mathrm{pH} 8)$, and mobile phase $\mathrm{B}$ was the same Tris- $\mathrm{HCl}$ buffer with $1 \mathrm{M} \mathrm{NaCl}$. The dotted line represents \% mobile phase B. The absorbance profile $(100 \%=0.05$ absorbance unit) was obtained using a wavelength of $280 \mathrm{~nm}$. The relative enzyme activity assay was performed at $37^{\circ} \mathrm{C}$ after a $50-\mu \mathrm{L}$ portion of the effluent fraction (upon appropriate dilution) was allowed to react with $50 \mu \mathrm{M}$ Phe-Pro for $10 \mathrm{~min}$. Both absorbance (\&OV0049;) and enzyme activities (-) were normalized against the highest value as shown in Figure 7.

respectively. After the inserts were relegated, they were sequenced with primers derived from human intestinal cDNA sequence. A 1807 nucleotide sequence of rat intestinal prolidase cDNA has been determined (Fig. 11A), which covers

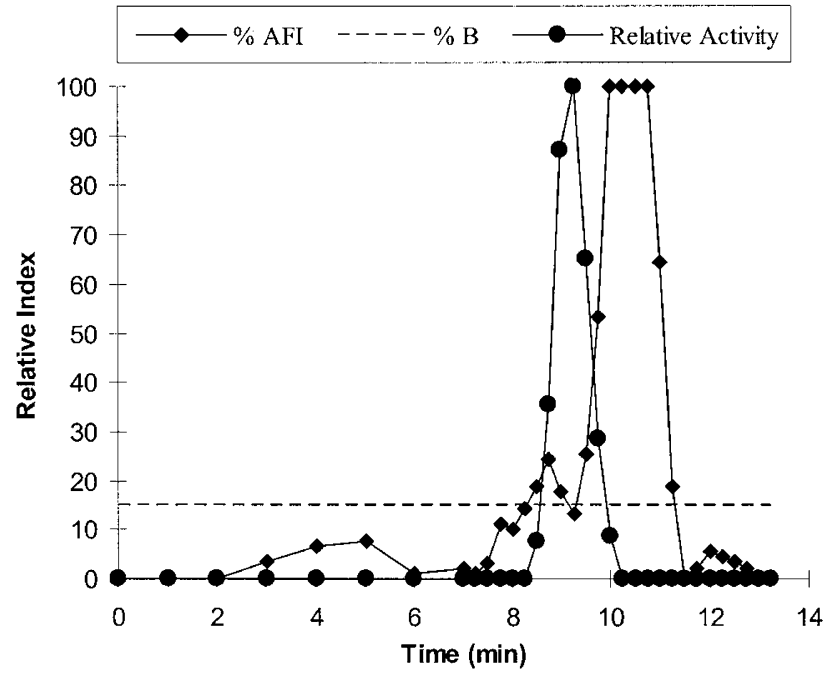

Figure 9. Elution profile of prolidase preparation through the SEC-400 S column $(0.6 \mathrm{~cm} \times 30 \mathrm{~cm})$. Mobile phase A was Tris-HCl buffer $(50 \mathrm{mM}, \mathrm{pH}$ 7.4), and mobile phase $\mathrm{B}$ was $\mathrm{A}$ plus $1 \mathrm{M} \mathrm{NaCl}$. The dotted line represents $\%$ mobile phase $B$. The absorbance values $(100 \%=0.025$ absorbance unit) were obtained using a wavelength of $280 \mathrm{~nm}$. The total activity assay was performed at $37^{\circ} \mathrm{C}$ after a $50-\mu \mathrm{L}$ portion of the effluent fraction was allowed to react with $50 \mu \mathrm{M}$ Phe-Pro for $10 \mathrm{~min}$. The eluted prolidase has a molecular weight of approximately $58,000 \mathrm{D}$, consistent with a molecular weight of approximately 59,000 D determined from SDS-PAGE gel (not shown). Both absorbance (\&OV0049;) and enzyme activities (-) were normalized against the highest value as shown in Figure 7.

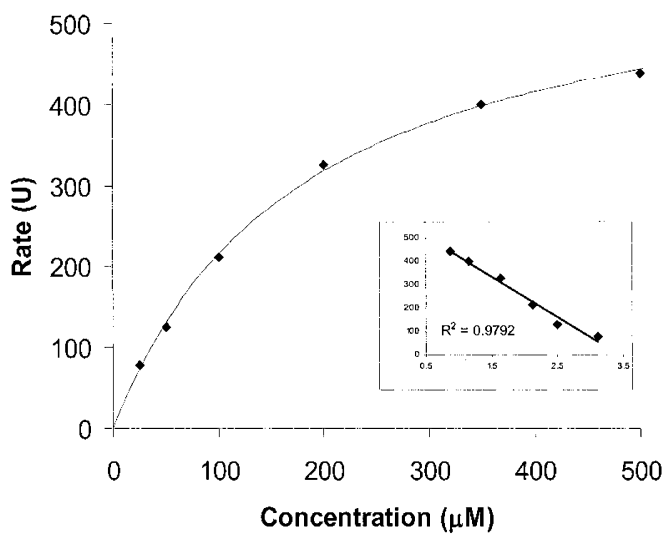

Figure 10. Effect of concentrations on the Phe-Pro hydrolysis by SEC-400S purified prolidase I. Experiments were performed at $37^{\circ} \mathrm{C}$ in $\mathrm{pH} 7.4 \mathrm{HBSS}$ buffer that contains $1 \mathrm{mM} \mathrm{Mn}^{++}$. The rate of hydrolysis was expressed as $\mathrm{U}$, which is equivalent to $1 \mu \mathrm{mol}$ of Phe-Pro hydrolyzed per minute per milligram of protein. The $\mathrm{K}_{\mathrm{m}}$ obtained was $178 \mu \mathrm{M}$ and $V_{\max }$ was $601 \mathrm{U}$, where $1 \mathrm{U}$ is $1 \mu \mathrm{mol} \cdot \min ^{-1} \cdot \mathrm{mg}$ protein ${ }^{-1}$. The Eadie-Hofstee plot of the data showed a straight line with an $r^{2}$ value of 0.979 , suggesting the presence of a single $K_{m}$ value. Each data point was the average of three determinations, and the error bars represent the SD of mean.

seven nucleotides upstream of initiating codon ATG and 318 nucleotides downstream from the stop codon TAG (as 1489 nucleotide). We then translated 1482 nucleotide sequence that codes 494 amino acids. Figure $11 B$ shows the amino acid sequence derived from the nucleotide sequence of the rat intestinal prolidase $1.8 \mathrm{~kb}$ cDNA. When comparing it to the prolidase amino acid sequences of the mouse and human intestine, the sequence identity was found to be $96 \%$ and $86 \%$, respectively. 
A

\begin{tabular}{|c|c|c|}
\hline $\begin{array}{l}\text { Rat } \\
\text { Mouse } \\
\text { Human }\end{array}$ & 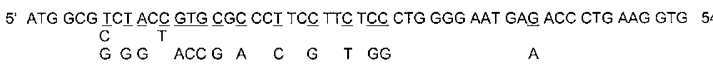 & 54 \\
\hline $\begin{array}{l}\text { Rat } \\
\text { Mouse } \\
\text { Human }\end{array}$ & 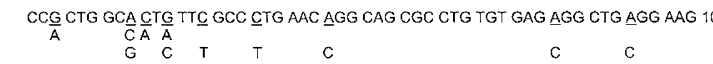 & 108 \\
\hline $\begin{array}{l}\text { Rat } \\
\text { Mouse } \\
\text { Human }\end{array}$ & 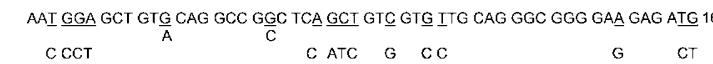 & 162 \\
\hline $\begin{array}{l}\text { at } \\
\text { ouse } \\
\text { uman }\end{array}$ & 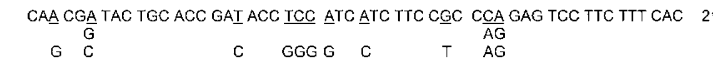 & 216 \\
\hline $\begin{array}{l}\text { at } \\
\text { ouse } \\
\text { uman }\end{array}$ & 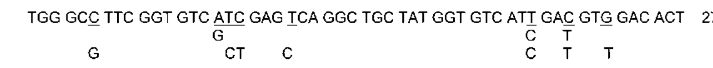 & 270 \\
\hline $\begin{array}{l}\text { th } \\
\text { tuse } \\
\text { uman }\end{array}$ & 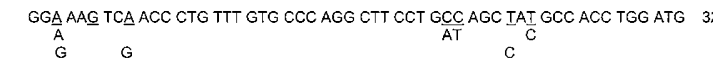 & 324 \\
\hline $\begin{array}{l}\text { at } \\
\text { ouse } \\
\text { Iman }\end{array}$ & 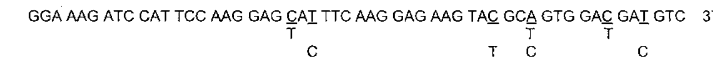 & 378 \\
\hline $\begin{array}{l}\text { Rat } \\
\text { Mouse } \\
\text { Human }\end{array}$ & 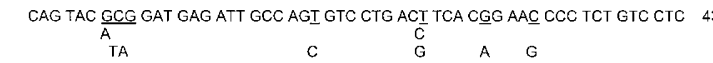 & 432 \\
\hline $\begin{array}{l}\text { at } \\
\text { ouse } \\
\text { uman }\end{array}$ & 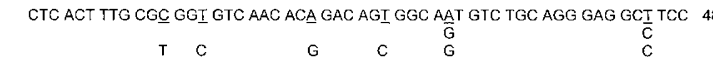 & 486 \\
\hline $\begin{array}{l}\text { Rat } \\
\text { Mouse } \\
\text { Human }\end{array}$ & 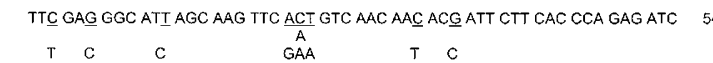 & 540 \\
\hline $\begin{array}{l}\text { Rat } \\
\text { Mouse } \\
\text { Human }\end{array}$ & 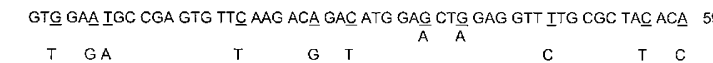 & 594 \\
\hline $\begin{array}{l}\text { Rat } \\
\text { Mouse } \\
\text { Human }\end{array}$ & $\begin{array}{ccc}\text { AAT } \underline{\text { CGG }} \text { ATC TCC AGT GAG GCC CAC CGT GAG GTA ATG AAG GCT GTA AAA GTG GGG } \\
\frac{\bar{C}}{\mathrm{AAA}} & \mathrm{C} & \mathrm{A}\end{array}$ & 648 \\
\hline $\begin{array}{l}\text { Rat } \\
\text { Mouse } \\
\text { HumanA }\end{array}$ & 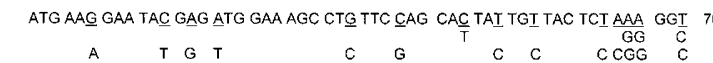 & 702 \\
\hline $\begin{array}{l}\text { Rat } \\
\text { Mouse } \\
\text { Human }\end{array}$ & 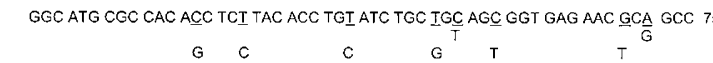 & 756 \\
\hline $\begin{array}{l}\text { Rat } \\
\text { Mouse } \\
\text { Human }\end{array}$ & 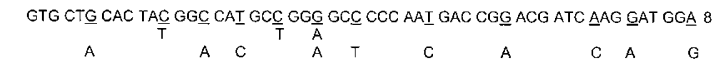 & 810 \\
\hline $\begin{array}{l}\text { Rat } \\
\text { Mouse } \\
\text { Human }\end{array}$ & 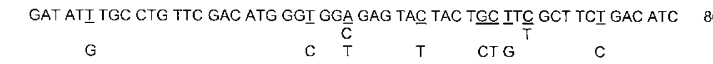 & 864 \\
\hline $\begin{array}{l}\text { Rat } \\
\text { Mouse } \\
\text { Human }\end{array}$ & 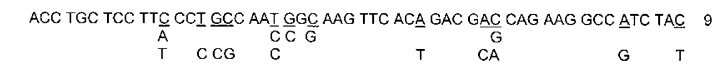 & 918 \\
\hline $\begin{array}{l}\text { Rat } \\
\text { Mouse } \\
\text { Human }\end{array}$ & 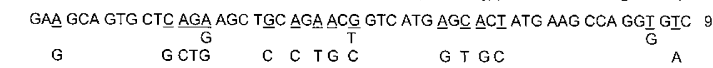 & 972 \\
\hline
\end{tabular}

B

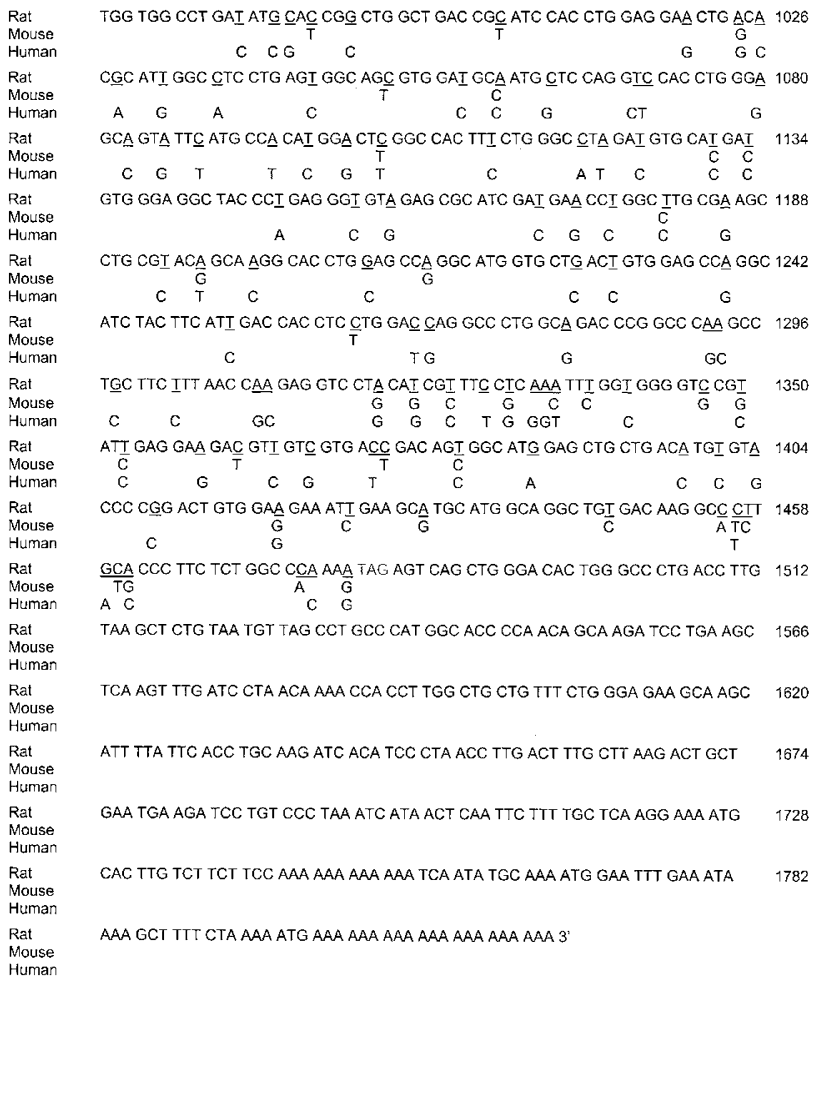

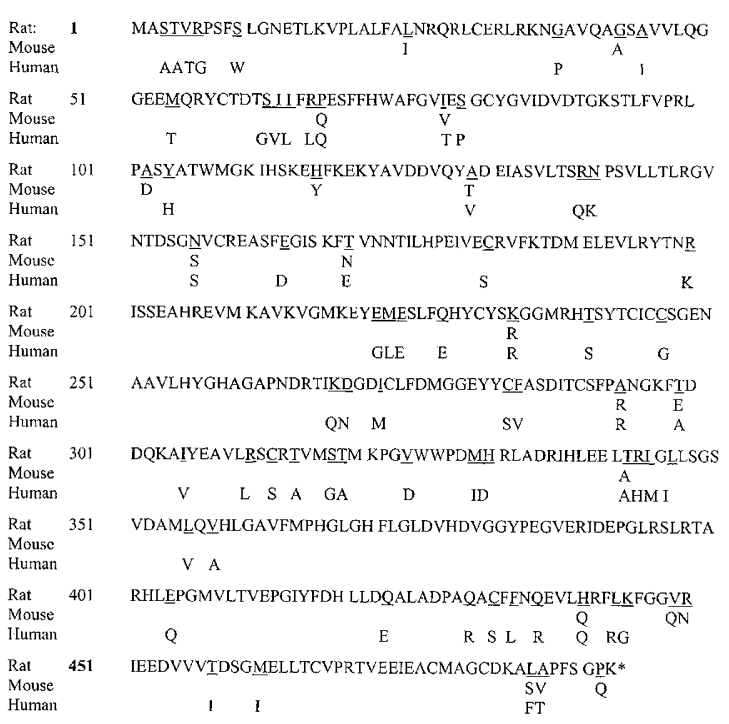

Figure 11. Nucleotide $(A)$ and deduced amino acid $(B)$ sequence of rat intestinal prolidase I. This sequence was derived from a rat intestinal cDNA library using a human prolidase probe as described in the text.

\section{Northern blot Analyses}

The jejunal (segment 4) prolidase mRNA level was determined to correlate with the activities difference between rats fasted for different periods of time (Fig. 12). When we removed the prolidase band and counted the radioactivities of radiolabeled probe associated with the band, we found that the ratio is $4: 1$ when contrasting rats fasted $24 \mathrm{~h}$ over rats fasted $48 \mathrm{~h}$ (not shown).

\section{DISCUSSION}

Prolidase is an important enzyme for protein metabolism, endogenous amino acid recycling, and proline-containing pro- 


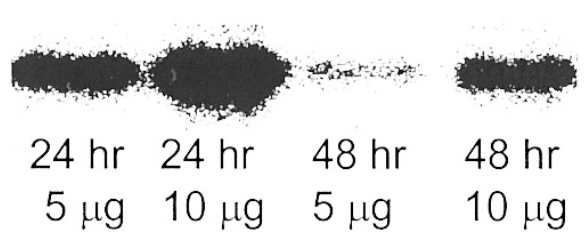

Figure 12. Northern blot analysis of total intestinal jejunal RNA with rat prolidase I cNDA probe. Total rat intestinal RNA was run on 1\% formaldehyde agarose gel and then transferred to nitrocellulose filter and hybridized with rat intestinal ${ }^{32} \mathrm{P}$-cNDA probe. The figure shows the autoradiograph of the actual blot after the blot was scanned using an HP ScanJet C4 using the import function of an Adobe Photoshop (version 5.0).

drug activation. Prolidase is not a well-studied enzyme, and its polymorphism is poorly understood, but it seemed to be present in patients who experienced prolidase deficiency (20). Therefore, the present study was undertaken to determine how prolidase is regulated in the intestine and to provide additional evidence in support of the presence of a second prolidase (or prolidase II) in the rat intestine.

We showed that the activity of prolidase in the jejunum was higher at $24 \mathrm{~h}$ postfeeding than that at $48 \mathrm{~h}$ postfeeding (Fig. 1). We then determined the distribution of prolidase along the rat intestine.

The distribution pattern of prolidase as measured by SA in the intestine at $24 \mathrm{~h}$ postfeeding is bell-shaped, and the maximal difference was 4.4 times (Fig. $2 A$ ). However, total prolidase activities per centimeter of intestinal segment showed a bigger difference between jejunum and colon (21 times) because total protein content of jejunal homogenate was at approximately five times higher than colon homogenate. This distribution pattern of prolidase is consistent with the expression pattern of an intestinal peptide carrier that mediates the absorption of small peptides $(23,24)$, because most of the activities were present in the jejunum. Working together, the delivery rate of amino acids to the systemic circulation, when given as small peptides, was the highest across the jejunum and lowest across the colon as observed previously (23).

The difference in activity observed at 24 and $48 \mathrm{~h}$ postfeeding was somewhat expected because amino acid transporters typically down-regulated when animals were fasted (25), suggesting the possibility that this enzyme may be regulated similarly. The results also indicated that the prolidase SA in the middle part of the small intestine (jejunum) was most sensitive to dietary regulation (Fig. 2). This result is consistent with the fact that jejunum is the main site where absorption of peptides occurs (23). However, starvation enhanced the expression of a peptide transporter (26), suggesting that prolidase is regulated differently from the peptide transporter. The latter is consistent with our observation of the same phenomenon in the Caco-2 cells (27).

To determine whether there was more than one component in the hydrolysis of Phe-Pro by crude prolidase preparation, we generated Eadie-Hofstee plots (Fig. 3D showed two representations). These plots provided evidence indicating the presence of a second component in the hydrolysis of Phe-Pro, because linear regression generated an $\mathrm{R}^{2}$ value of approximately $0.7-$ 0.8. In contrast, an Eadie-Hofstee plot generated using purified prolidase has an $\mathrm{R}^{2}$ value of 0.979 (Fig. 10). The effect of $\mathrm{pH}$ also generated some additional evidence in support of the two-isozyme hypothesis in that prolidase activities in the jejunum (segment 4) was much more sensitive to $\mathrm{pH}$ change when $\mathrm{pH}$ increased from $\mathrm{pH} 7$ to $\mathrm{pH} 8$, whereas duodenum prolidase activities were more sensitive to $\mathrm{pH}$ change when it decreased from $\mathrm{pH} 6$ to $\mathrm{pH}$ 5. Finally, jejunal prolidase activities were inhibited more by zinc chloride and proline than duodenum and colon prolidase activities. However, further kinetic analysis of purified prolidase II or expressed prolidase II will be needed to confirm these preliminary observations that indicated the presence of prolidase II.

We attempted but were unable to purify prolidase II using the conditions described. One possibility is that the Resource-Q column is of lower resolution power, because we were unable to use this column to separate two isozymes (results not shown) from human blood samples using a published procedure (21). It is also possible that the majority of prolidase II activity was lost by the time we passed the sample through the Resource-S column, because it was reported that DEAE-Sephadex (also a cation exchanger) chromatography removed prolidase II activity (22). Alternatively, the two isozymes in the rat intestine are highly different from those found in other species, which prevent their separation. The latter possibility is less likely because prolidase I is well conserved from swine to humans, and the rat intestinal prolidase I also seemed to have a similar molecular weight (approximately 58,000 D for the monomer). We also tried to clone the prolidase II from the rat intestinal cDNA library using the rat intestinal prolidase I cDNA as the probe, but we did not find any unique sequence among the many positive clones $(>10)$ generated using less stringent washing condition in the selection of positive clones.

In conclusion, we have successfully purified intestinal prolidase I, which has not been obtained before in the intestine of any species (the highest specific activities reported previously for intestinal prolidase was $8.7 \mathrm{U}(28)$ ). This represents a significant advance because a recent effort to purify prolidase I from the human intestine was reported to be unsuccessful (22). The purity $(510 \mathrm{U})$ obtained from our procedure is better than those obtained by Endo et al. (SA = $167 \mathrm{U})(17)$ and Ritcher et al. (200 U) (18) but less than that obtained by Myara et al. using human kidney (SA = $613 \mathrm{U})$ (22). However, we used fewer steps to arrive at our high SA. When we sequenced rat intestinal prolidase, we found that the enzyme sequence is very similar to mouse (96\% sequence identity) or human $(86 \%)$ prolidase I sequence derived from their erythrocytes.

In addition to the purification of rat intestinal prolidase I, we were able to demonstrate that the activity of prolidase was site dependent with highest activities in the jejunum. The latter distribution pattern is consistent with peptide absorption pattern observed in rats in vivo (23). The results also indicated that fasting had different effects on the duodenal, jejunal, and colonic prolidase activities, with the jejunal prolidase as the one most prone to dietary regulation. Finally, the results of $\mathrm{pH}$ effects and the differences and similarities between $\mathrm{K}_{\mathrm{m}}$ values and Eadie-Hofstee plots suggest the possibility of intestinal prolidase polymorphism. Future studies that identify additional 
isozymes will help further elucidate the physiologic functions of intestinal prolidase.

\section{REFERENCES}

1. Emmerson KS, Phang JM 1993 Hydrolysis of proline dipeptides completely fulfills the proline requirement in a proline-auxotrophic Chinese hamster ovary cell line. $\mathrm{J}$ Nutr 123:909-914

2. Yaron A, Naider F 1993 Proline-dependent structural and biological properties of peptides and proteins. Crit Rev Biochem Mol Biol 28:31-81

3. KokturkA, Kaya TI, Ikizoglu G, Koca A 2002 Prolidase deficiency. Int J Dermato 41:45-48

4. Fimiani M, Rubegni P, de Aloe G, Bilenchi R, Andreassi L 1999 Squamous cell carcinoma of the leg in a patient with prolidase deficiency. Br J Dermatol 140:362363

5. Bissonnette R, Friedmann D, Giroux JM, Dolenga M, Hechtman P, Der Kaloustian VM, Dubuc R 1993 Prolidase deficiency: a multisystemic hereditary disorder. J Am Acad Dermatol 29:818-821

6. Myara I, Charpentier C, Lemonnier A 1984 Prolidase and prolidase deficiency. Life Sci 34:1985-1998

7. Moolenaar SH, Engelke UF, Abeling NG, Mandel H, Duran M, Wevers RA 2000 Prolidase deficiency diagnosed by $1 \mathrm{H}$ NMR spectroscopy of urine. J Inherit Metab Dis 24:843-850

8. Ganapathy V, Pashley SJ, Roesel RA, Pashley DH, Leibach FH 1985 Inhibition of rat and human prolidase by captopril. Biochem Pharmacol 34:1287-1291

9. Achord JL 1989 Cirrhosis of the liver: new concepts. Compr Ther 15:11-16

10. Stein HD, Keiser HY, Sjoerdsma A 1970 Proline-hydroylase activity in human blood Lancet 1:106-109

11. Bielawska A, Chrzanowski K, Bielawski K, Palka J 2001 Decreased cytotoxicity and increased antimitotic activity of a proline analogue of chlorambucil as a prodrug susceptible to the action of fibroblast's prolidase. Pharmazie 56:290-294

12. Bai JP, Hu M, Subramanian P, Mosberg HI, Amidon GL 1992 Utilization of peptide carrier system to improve intestinal absorption: targeting prolidase as a prodrugconverting enzyme. J Pharm Sci 81:113-116

13. Dolenga M, Hechtman P 1992 Prolidase deficiency in cultured human fibroblasts: biochemical pathology and iminodipeptide enhanced growth. Pediatr Res 32:479482
14. Bradford M 1976 A rapid and sensitive method for the determination of microgram quantities of protein utilizing the principles of protein-dye binding. Anal Biochem $72: 248-254$

15. Endo F, Matsuda I, Ogata A, Tanaka S 1982 Human erythrocyte prolidase and prolidase deficiency. Pediatr Res 16:227-231

16. Endo F, Motohara K, Indo Y, Matsuda I 1987 Immunochemical studies of human prolidase with monoclonal and polyclonal antibodies: absence of the subunit of prolidase in erythrocytes from a patient with prolidase deficiency. Pediatr Res 22:627-633

17. Laemmli UK 1970 Cleaving of structural proteins during the assembly of the head of bacteriophage T4. Nature (London) 222:680-685

18. Richter AM, Lancaster GL, Choy FYM, Hechtman 1989 Purification and characterization of activated human erythrocyte prolidase. Biochem Cell Biol 67:34-41

19. Hu M, Chen J, Tran D, Zhu Y, Leonardo G 1994 The Caco-2 cell monolayers as an intestinal metabolism model: metabolism of dipeptide Phe-Pro. J Drug Target $2: 78-89$

20. Kodama H, Ohhashi T, Ohba C, Ohno T, Arata J, Kubonishi I, Miyoshi I 1989 Characteristics and partial purification of prolidase and prolinase from leukocytes of a normal human and a patient with prolidase deficiency. Clin Chim Acta 180:65-72

21. Myara I, Moatti N 1989 Separation of two erythrocyte prolidase isoforms by fast protein liquid chromatography: application to prolidase deficiency. J Chromatogr A 489:170-175

22. Myara I, Cosson C. Moatti N, Lemonnier A 1994 Human kidney prolidasepurification, preincubation properties and immunological reactivity. Int $\mathrm{J}$ Biochem 26:207-214

23. Adibi SA, Morse EL 1971 Intestinal transport of dipeptides in man: relative importance of hydrolysis and intact absorption. J Clin Invest 50:2266-2275

24. Shen H, Smith DE, Brosius 3rd FC 2001 Developmental expression of PEPT1 and PEPT2 in rat small intestine, colon, and kidney. Pediatr Res 49:789-795

25. Cheeseman CI 1991 Molecular mechanisms involved in the regulation of amino acid transport. Prog Biophys Mol Biol 55:71-84

26. Ihara T, Tsujikawa T, Fujiyama Y, Bamba T 2000 Regulation of PepT1 peptide transporter expression in the rat small intestine under malnourished conditions. Digestion 61:59-67

27. Hu M, Zheng L, Chen J, Liu L, Li Y, Dantzig AH, Stratford Jr RE 1995 Peptide transporter function and prolidase activities in Caco-2 cells: a lack of coordinated expression. J Drug Target 3:291-300

28. Yoshimoto T, Matsubara F, Kawano E, Tsuru D 1983 Prolidase from bovine intestine: purification and characterization. J Biochem 94:1889-1896 